\begin{tabular}{ccc}
\hline Mournals & MARKETING AND BRANDING & $\begin{array}{c}\text { INDUSTRIAL } \\
\text { RESEARCH } \\
\text { MANAGEMENT } \\
\text { AIMI }\end{array}$ \\
\hline \hline
\end{tabular}

\title{
Measurement of intra-industry trade (ITT) of Iran with ten selective major trading partners using Grubel-Lloyd Index
}

\author{
Muhammad Emadi
}

M.A. Student in Economic Sciences, Shiraz Branch, Islamic Azad University, Shiraz, Iran

\begin{abstract}
Keywords:

Intra-Industry Trade,

Grubel-Lloyd Index

This paper was conducted to measure intra-industry trade of Iran with ten selective major trading partners including the United Arab Emirates, Germany, China, Republic of Korea, Italy, India, Japan, Turkey, Spain, and Singapore using Grubel-Lloyd index. Due to the development of cross-border economic relationships, these countries try to find and present an appropriate model for production, import, and export of goods and identification of business opportunities and comparative advantages. Therefore, intra-industry trade of products helps countries to consider the differences between their real commercial comparative advantages and other countries and then try to find new technologies in their

Correspondence: Iran.names@gmail.com production. It can be found from estimation the average of Iran's intra-industry trade with its major trading partners that most of Iran's trade volume during the studied period belongs to India with an average of 66.43 per cent. In other words, India is the largest trading partner of Iran in terms of intra-industry trade.
\end{abstract}

(C)AIMI Journals

\section{Introduction}

Intra-industry trade has attracted a lot of international economists' attention almost four decades ago. According to traditional trade theory, trade in goods with similar factor intensities is similar between countries (Brulhart \& Thorpe, 2000). In other words, international trade theories only explain trades among industries and do not refer to intraindustry trade (Markusen \& Venables, 2002). According international trade theory, a significant portion of international trade remains unexplained especially among developing countries. Moreover, traditional theories are mainly associated with the structural differences in countries' trade in the terms of their technology, inventory factors, and preferences. Intraindustry trade is an empirical phenomenon that has been found in international trade over 
recent years. This type of trade refers to the exchange of the same types of goods or services which have been produced, exported, and imported within the same industry (Azarbayjani \& Izadi, 2006).

The evaluation of intra-industry trade between the two countries is considered important from various aspects. Firstly, investigating this phenomenon in terms of its bilateral relations depicts that which business theories (traditional or new) are more appropriate to explain this process. Secondly, increasing international trade of a country causes changes in the size and quantity of trade, export, and imports. There is a converse relationship among these changes, as one variable increases, the other one decreases. The important point is that as one of these variables decreases, the production resources on that field get freed up and leads to actual displacement of factors. If the freed resources especially human resources are not absorbed by other sectors, they will remain unemployed which lead into the economic imbalance. Defining and determining the extent of intra-industry trade in different groups of industrial goods can specify industries which are vulnerable in the process of trade liberalization between countries (Afshar \& Soleimani Movahhed, 2010).

Since the countries for the development of cross-border economic relations are in search of suitable model for their productions, imports, and exports of goods, identifying trading opportunities and comparative advantages are of relative importance (Abdel-El-Rahman, 1991). Therefore, intra-industry trade helps countries to take into account the real comparative advantage of their commercial productions with other countries and find the new technologies in production. Considering the factors affecting the intra-industry trade and applying Grubel and Lloyd index, this paper tries to calculate intra-industry trade of Iran with ten selective major trading partners by from 1992 to 2011.

\section{The Literature Review}

Rasekhi and Shojaee (2012) investigated the country-specific determinants of vertical and horizontal intra-industry trade in Iran. According to the statistical data which obtained from 1997 to 2003 and using panel method and Grubel and Lloyd index, Fontagne and Freudenberg (1997) categorized trade flows and computed the share of each category as determinant in trade of countries such as Iran, Indonesia, Brazil, Pakistan, Turkey, China, the Philippines, Mexico, India, Singapore, South Korea, and Malaysia. The overall intra-industry trade on the basis of appropriate explanatory variable has confirmed in terms of measurement error, theory, and econometrics. A panel model for estimating country-specific determinants of horizontal and vertical intra-industry trade is presented in equation 1 :

\section{(1) EET $=\alpha+X_{p t} \beta+U_{p t}$}

As noted in equation 1, the index IIT $_{\mathrm{pt}}$ stands for index vector of horizontal and vertical intra-industry trade for $\mathrm{p}$ number of countries during t period of time. $\mathrm{X}_{\mathrm{pt},} \mathrm{U}$ pt, $\alpha$, and $\beta$ represent a set of $\mathrm{k}$ explanatory variable, disturbing elements of vector model, fixed parameter vector, vector of explanatory coefficients variable, respectively. The findings reveal the level of growth and development, market size, Linder variable, equal participation 
in economic arrangements, similarities between tariffs, tariff barriers, product differentiation, and cultural similarities of determinants of horizontal intra-industry trade in selected countries (Baier \& Berystrand, 2001; Sawyer, Sprinkle, \& Tochkov, 2009). In addition to the above mentioned factors, income distribution and geographical distance are effective in determining the vertical intra-industry trade (Ando, 2006).

Although the growth and development naturally expands types of horizontal and vertical intra-industry trade, it seems that proper attention to the determinants of intra-industry trade particularly product differentiation, market size, foreign direct investment, trade liberalization, participation in regional economic arrangements lead to further development of intra-industry trade within countries. The results showed that among surveyed countries the countries such as Singapore, Mexico, and South Korea have the highest intra-industry trade share in 1997. The volume of intra-industry trade of these countries has been estimated 74.91, 54.04, and 51.08 per cent, respectively while this volume has been estimated 73.6 per cent for intra-industry trade. In 2003, Singapore, Malaysia, and Mexico have allocated the highest volume of non-reciprocal intra-industry trade. These volumes in 2003 were 74.02, 57.31, and 56.77 per cent, respectively. Even the volume of Iran's intra-industry trade has increased to 10.58 per cent in 2003. However, the volume of non-reciprocal intra-industry trade of Iran only was more than Pakistan and less than any other country in survey.

Shahbaz and Leitao (2010) surveyed the intra-industry trade of Pakistan and identified the importance of economies of scale and product diversification during the period 2006-1998. They used country-specific indices as an explanatory variable in their model. Surveyed model is as follows:

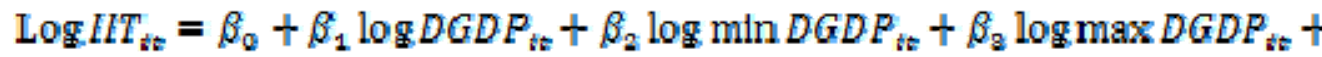 $\beta_{4} \log D I M_{t t}+\beta_{6} \log D I S T_{t}+\beta_{6} \log F D L_{t t}+\beta_{7} \log T L M B+\delta t+\varphi \eta t+\epsilon t$}

In equation 2, the logarithm of $I I T_{t w} i$ refers to the intra-industry trade at $t$ time, $D G D P_{t}$ represnets the similarity between the $i$ number of trading partners of Pakistan at $t$ time.

$$
\text { (3) }\left(\max G D P_{t}\right) \min G D P_{t=} \cdot \log \left|G D P_{\text {gakegtan }}-G D P_{\text {partwerg }}\right|
$$

In equation 3, $i$ shows the minimum and maximum of Pakistan's gross domestic product (GDP) and its trading partners. L $\mathrm{gg} D L M_{t}$ represents the logarithm of average GDP of two trading partners while $\log D E S T_{t:}$ stands for the geographical distance between Pakistan and its trading partners and $i$ for business partner at $t$ time. LogFDI $I_{i t}$ refers to the flow of direct investment at $t$ time, $\log T$ FM $B$ to the balanced trade, $\eta i$ intangible effects of time instability, $\delta t$ to the definite trend or process, and $\varepsilon$ it to the random disruption.

The results showed that intra-industry trade has negative function of the difference in GDP per capita between Pakistan and its trading partners. It also stated that transportation costs reduction increase the amount of trade. Furthermore, previous studies indicated that 20 per cent of Pakistan's trade is in the form of intra-industry trade which showed the difference in GDP per capita income between Pakistan and its trading partners. 
Xing (2007) examined the foreign direct investment and China's bilateral intra-industry trade with Japan and America in the period of 1980-2004. His study revealed that how much foreign direct investment in Japan and America affects the development of China's bilateral intra-industry trade. The model of his study is as follows:

$$
\text { (4) } \log I F T_{t}=\beta_{0}+\beta_{1} \log F D E_{t}(t-1)+\beta_{2} G D P D_{t}+\beta_{3} \log T B_{t}+\epsilon
$$

In equation $4, E I T_{t t}$ represents the bilateral intra-industry trade index in $i$ part while $F D L_{i}(t-1), G D P D_{\varepsilon}, T E_{z}, O P E N_{t}$, and $\in$ refer respectively to the foreign direct investment in $i$ part at $t$ time, the difference in GDP of China and its trading partners, trade balance between China and trading partners when trade balance is greater the share intra-industry trade of the growth of total trade, tradlo openness of China which refers to the direct relationship between the economic openness and intra-industry trade, and disturbance.

The results indicated that the rapid increase in intra-industry trade in developing countries such as China may cause to the attempts to increase the diversity of productions, improve the economies of scale, and reduce the technology gap with its trading partners. Moreover, Japan's foreign direct investment plays a productive role in the bilateral intraindustrial trade with China which increases China's intra-industry trade to 15 per cent.

Cernos (2007) investigated the horizontal and vertical intra-industry trades of European countries such as Czech Republic, Hungary, Poland, Slovenia, and Slovakia in foreign trade with the members of Europe Union in the period 2001-1995 at standard international trade classification (SITC) level.

$$
\begin{gathered}
(5) \beta_{j}=\mathrm{H} \beta_{i}+\mathrm{V} \beta_{i} \\
\tilde{p}_{i}=\left[\left(x_{i}+w f_{i}\right)-\left(x_{i}-m f_{i}\right)\right] \frac{100 \gamma_{i}}{\left(x_{t}+m_{i}\right)}
\end{gathered}
$$

In equation $5, \beta_{\mathrm{i}}$ stands for Grubel and Lioyd index for $i$ industry, $\mathrm{V} \beta_{\mathrm{i}}$ for vertical intraindustry trade for $i$ industry, $\mathrm{H} \beta_{i}$ for horizontal intra-industry trade for $i$ industry, $X_{i}$ for export in $i$ industry, $\mathrm{M}_{\mathrm{i}}$ for import in $i$ industry, $\mathrm{UV}^{\mathrm{x}}$ for export unit value, and $\mathrm{UV}^{\mathrm{m}}$ for import unit value. The findings revealed that the vertical and horizontal intra-industry trade of the mentioned countries allocates to the production of low quality goods in a vertically differentiated industry. Also, surveying intra-industry trade in manufacturing activities indicates that among these activities such as textile production, luggage construction, nonmetallic mineral products, construction of electronic machinery only a few of them have high-quality vertical product differentiation. But in most cases, this vertical production differentiation is associated with low quality. This means that only 25 per cent of these countries trade possess high quality vertical intra-industry trade.

\section{Method}

Intra-industry trade is divided into two categories, namely horizontal intra-industry trade and vertical intra industry trade (Byun \& Lee, 2005). Horizontal intra-industry trade is a twoway exchange of goods at different stages of the production. It means that two main types of products only differ in a few superficial features not in their quality such as color and size differences (Azarbayjani \& Taati, 2011; Rasekhi, 2007, 2008; Rasekhi \& Shojaee, 2012). Vertical intra-industry trade refers to the trade in products with different qualities. In order to 
measure this distinctiveness, the value of export and import units is used. By determining a certain limit $(\alpha)$ and the extent or range in which the ratio of export to import unit values placed, the types of a product differentiation and their quality can be identified. Determining the amount of mentioned limit which is called product similarity depends on the researchers' identification. Greenaway and Milner (1986) considered this value 25 per cent while Fontagne and Freudenberg (1997) considered it 15 per cent. Equations 6 and 7 represent goods differentiation in which $U V_{j k}^{X}$ shows the value of exports of product $X$ in industry $j$ and in country $k$ and $U V_{j k}^{m}$ indicates the value of imports of product $m$ in industry $j$ in country $k$.

$$
\begin{aligned}
& \text { (6) If } 1-\alpha \leq \frac{w_{j k}^{Z}}{b w_{j i}^{m}} \leq 1+\alpha \Rightarrow \text { Horizontal differentiation }
\end{aligned}
$$

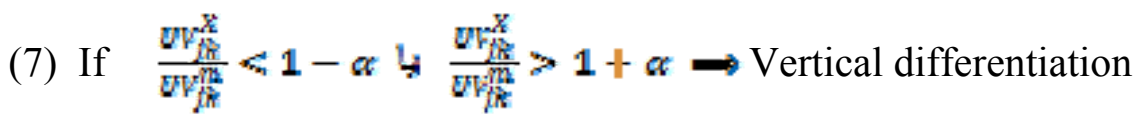

\section{Importance of Horizontal and Vertical Intra-Industry Trade}

Identification of quality-differentiated goods in bilateral trade between two countries can be helpful in several aspects (Yuqing, 2007). First, the overall properties of the productions, countries which are business competitors and domestic export goods should be determined. Furthermore, determining of type of differentiation can specify the amount of competitive pressure on the exports on the market of receiver country. The dominance of the horizontal intra-industry trade indicates the competitive pressure. The high share of horizontal intraindustry trade indicates the large number of export substitutions; therefore, the amount of competitive pressure on internal producers will increase. Conversely, if the share of intraindustry trade increases, it will reflect the consumers with different preferences and income levels in the market of receiver country. It also shows that there is little competitive pressure on exports and the same products with different quality cannot perfectly substitute with each other. In this case, the competition is done to gain a higher market share till the consumer can choose from a wide variety of products with different prices.

\section{Intra-Industry Trade Indices}

Intra-industry trade refers to the exchange of the same products at the same time which belong to the same industry. This index was proposed by Grubel and Lloyd (1975) to measure intra-industry trade has attracted much attention. In equation 8 , this index measures the degree of overlap in trade for industry $j$ in which $X_{j}$ and $M_{j}$ show exports and imports in industry $j$, respectively. Moreover, equations 8 and 9 help to calculate the volume of intraindustry trade.

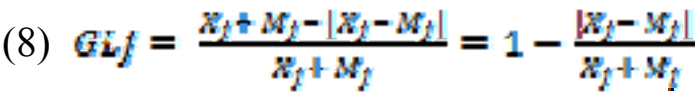

$$
\begin{aligned}
& \text { (9) } I I T f=X_{j}+M_{f}-\left|X_{f}-M_{f}\right|
\end{aligned}
$$

In other words, intra-industry trade is the balanced part of total bilateral trade. Despite the widespread and successful empirical application of Grubel and Lloyd index in previous studies, it suffers from two main drawbacks including geographical and sectoral aggregation 
bias. Geographical bias arises from an insufficient disaggregation of partner countries when different partner countries are put together before doing the calculations. Normally, the selected country may have no intra-industry trade, but due to geographical bias, a complete overlap in the trade of country may be observed. On the other hand, sectoral aggregation bias results from inadequate integration in trade classifications, and if in extreme mode we classify the products as one industry, it will consist of a significant part of intra-industry trade. Therefore, the probability of overlap between imports and exports in that industry will be greater as the products in that industry aggregate more. Gray (1979) noted aggregation bias can occur due to an opposite sign effect and a weighting effect depending upon subgroup trade imbalances and its magnitude. Thus, the Grubel and Lloyd index depends on the aggregational level of the data, it decreases when the level of aggregation become lower even if there is no intra-industry trade in practice. In the literature, many researchers have effectively used the unadjusted Grubel-Lloyd index to measure intra-industry trade (Caves, 1981; Vona, 1991). Vona (1991) stated that two things may be occur as consequence if the level of integration reduces. First, if the symptoms of imbalance in each subdivision are the same with the symptoms of general imbalance, the estimated index in different levels of aggregation will be the same. Second, if the imbalances in each subdivision are different, intra-industry trade index will decrease with the reduction of aggregation. He also believed that if the correct definition of industry does not present, the separation of sections into subsection will not correct and lead to the underestimation of intra-industry trade. So, for accurate measurement of intra-industry trade, we should take action to reduce the level of data aggregation immediately and provide a suitable definition from the industry. One of the criticisms which has been proposed related to the Grubel and Lioyd index is that the limit of this index places between 0 and 1 but as soon as the total trade becomes unbalanced, total intra-industry trade cannot completely demonstrate. Therefore, the economists proposed a modified version of Grubel and Lioyd index in order to improve the overall trade imbalance and then divided international trade into three distinct parts including intra-industry trade (the balanced part of trade), trade among industries, and the imbalance section of trade. Grubel and Lloyd also suggested a way to correct their index. In their proposed index, we should subtract the total trade imbalance from the total trade of the country (Markusen \& Venables, 2002). Equation 10 indicates how to calculate the modified index of Grubel and Lloyd. In this case, intra-industry trade is more than the share of overlap trade in total balanced trade.

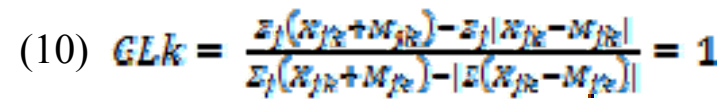

\section{Results}

Equation 11 represents Grubel and Lioyd index which is used to measure intra-industry trade of Iran with ten selective major trading partners. Table 1 presents the results for measurement of Grubel and Lioyd index.

$$
G L=\frac{\left(M_{i}+M_{i}\right)-\left|M_{i}-M_{i}\right|}{\left(M_{i}+M_{i}\right)} \times 100=\left[1-\frac{\left|H_{i}-M_{i}\right|}{\left(B_{i}+M_{i}\right)}\right] \times 100
$$


Table 1

Results for Measurement of Grubel and Lloyd Index

\begin{tabular}{|c|c|c|c|c|c|}
\hline Name of Countries & 1992 & 1993 & 1994 & 1995 & 1996 \\
\hline United Arabic Emirates & 63.70 & 48.21 & 85.15 & 80.53 & 70.30 \\
\hline Germany & 8.53 & 36.24 & 69.39 & 57.78 & 42.70 \\
\hline China & 60.61 & 99.44 & 95.04 & 47.65 & 46.68 \\
\hline Republic of Korea & 4.11 & 9.95 & 27.25 & 27.61 & 30.18 \\
\hline Italy & 14.24 & 31.30 & 62.51 & 64.21 & 46.64 \\
\hline India & 13.27 & 53.16 & 85.38 & 80.73 & 68.51 \\
\hline Japan & 4.37 & 8.88 & 34.36 & 25.64 & 21.03 \\
\hline Turkey & 10.13 & 97.13 & 98.76 & 81.12 & 64.05 \\
\hline Spain & 9.97 & 24.41 & 45.86 & 29.97 & 26.59 \\
\hline \multirow[t]{2}{*}{ Singapore } & 30.85 & 53.53 & 68.98 & 53.68 & 47.80 \\
\hline & 1997 & 1998 & 1999 & 2000 & 2001 \\
\hline United Arabic Emirates & 67.39 & 80.95 & 87.64 & 54.01 & 56.39 \\
\hline Germany & 34.86 & 39.63 & 46.87 & 37.25 & 29.49 \\
\hline China & 27.21 & 24.70 & 19.87 & 44.05 & 33.29 \\
\hline Republic of Korea & 29.36 & 12.59 & 15.85 & 17.11 & 9.87 \\
\hline Italy & 51.47 & 29.10 & 33.25 & 36.07 & 32.25 \\
\hline India & 58.47 & 83.01 & 78.44 & 73.21 & 50.02 \\
\hline Japan & 21.16 & 8.20 & 17.65 & 28.26 & 31.42 \\
\hline Turkey & 47.55 & 73.61 & 89.24 & 83.01 & 33.36 \\
\hline Spain & 16.07 & 22.16 & 28.19 & 25.71 & 40.44 \\
\hline \multirow{2}{*}{ Singapore } & 59.17 & 44.89 & 49.43 & 42.90 & 43.03 \\
\hline & 2002 & 2003 & 2004 & 2005 & 2006 \\
\hline United Arabic Emirates & 51.88 & 58.89 & 51.49 & 33.48 & 31.20 \\
\hline Germany & 14.21 & 16.54 & 19.36 & 12.90 & 13.20 \\
\hline China & 31.87 & 35.66 & 33.67 & 38.71 & 55.34 \\
\hline Republic of Korea & 10.54 & 9.63 & 21.52 & 12.37 & 21.16 \\
\hline Italy & 20.26 & 21.40 & 31.11 & 18.35 & 54.64 \\
\hline India & 41.77 & 57.66 & 50.22 & 81.31 & 73.49 \\
\hline Japan & 49.76 & 66.18 & 51.16 & 58.23 & 24.26 \\
\hline Turkey & 43.56 & 5.69 & 39.61 & 38.19 & 53.65 \\
\hline Spain & 49.63 & 49.62 & 63.98 & 56.41 & 57.88 \\
\hline \multirow[t]{2}{*}{ Singapore } & 33.99 & 37.40 & 29.04 & 22.45 & 36.96 \\
\hline & 2007 & 2008 & 2009 & 2010 & 2011 \\
\hline United Arabic Emirates & 31.68 & 29.37 & 30.69 & 27.21 & 37.22 \\
\hline Germany & 13.12 & 11.22 & 13.87 & 14.04 & 21.48 \\
\hline China & 44.93 & 58.64 & 78.42 & 88.12 & 75.45 \\
\hline Republic of Korea & 36.70 & 41.81 & 27.08 & 27.32 & 45.17 \\
\hline Italy & 43.08 & 28.24 & 37.35 & 32.35 & 25.75 \\
\hline India & 72.99 & 77.86 & 82.72 & 83.17 & 63.40 \\
\hline Japan & 82.31 & 60.93 & 40.37 & 44.07 & 56.55 \\
\hline Turkey & 62.44 & 52.01 & 45.31 & 41.80 & 60.32 \\
\hline Spain & 67.05 & 58.79 & 53.57 & 52.30 & 6.25 \\
\hline Singapore & 27.32 & 18.70 & 19.75 & 27.20 & 87.98 \\
\hline
\end{tabular}

The analysis of mean scores of ten selective major trading partners in Table 1 represents that the highest and the lowest level of intra-industry trade belong to India and South Korea, respectively. Table1 also reflects the difference between Iran's intra-industry trade and other countries.

Table 2 
Average of Intra-Industry Trade

\begin{tabular}{lc}
\hline Country & Mean Score \\
\hline United Arabic Emirates & 66.43 \\
Germany & 56.02 \\
China & 54.03 \\
Republic of Korea & 51.96 \\
Italy & 41.72 \\
India & 39.24 \\
Japan & 36.73 \\
Turkey & 35.67 \\
Spain & 37.61 \\
Singapore & 21.82 \\
\hline
\end{tabular}

As it is obvious in Table 2, India with mean score of 66.43 allocates the highest level of intra-industry trade with Iran and South Korea with mean score of 21.82 has the lowest level of intra-industry trade with Iran.

\section{Conclusion}

This study tried to measure intra-industry trade of Iran with ten selective major trading partners including the United Arab Emirates, Germany, China, Republic of Korea, Italy, India, Japan, Turkey, Spain, and Singapore using Grubel-Lloyd index. Measuring the mean scores of intra-industry trade of these countries showed that the highest volume of intraindustry trade is related to India with mean score 66.43. The minimum volume of intraindustry trade in the selected period of time among Iran and its ten selective major trading partners belongs to South Korea with mean score of 21.82. Finally, Iran's the second largest trade partner in the studied period in terms of intra-industry trade is Turkey with mean score of 56.02 .

\section{References}

Abdel-El- Rahman, K. (1991). Firms' competitive and national comparative advantages as joint determinants of trade composition. Review of World Economics, 127(1), 83-97.

Afshari, Z., \& Soleymani Movahhed, M. (2010). The test of Heckscher-Ohlin-Samuelson theory in intra-industry trade of Iran (A dynamic panel approach). Quarterly Iranian Journal of Trade Studies, 14(54), 1-23.

Ando, M. (2006). Fragmentation and vertical intra-industry trade in East Asia. North American, Journal of Economics \& Finance, 17(3), 257-281.

Azarbayjani, K., \& Taati, S. (2011). The features of vertical intra-industry trade: Panel data approach. Quarterly Journal of Economic Research \& Policies, 19(57), 57-82.

Azarbayjani, K., \& Izadi, G. (2006). Iran's intra-industry with China: A new perspective. Iran's Economic Quarterly Journal, 26, 81-99.

Baier, S. L., \& Berystrand, J. H. (2001). The growth of world trade: Tariffs, transport costs, and income similarity. Journal of International Economics, 53(1), 1-27.

Byun, J., \& Lee, S. (2005). Horizontal and vertical intra-industry trade: New evidence from Korea, 1991-1999. Global Economy Journal, 5(1), 1-29.

Brulhart, M., \& Thorpe, M. (2000). Intra-industry trade adjustment in Malaysia: Puzzling evidence. Applied Economics Letters, 7(11), 729-733.

Caves, R. E. (1981). Intra-industry trade and market structure in the industrial countries. Oxford Economic Papers, 33, 203223. 
Cernos, S. (2007). Horizontal and vertical intra-trade between the former SEFTA countries and European Union. Managing Global Transitions, 15(2), 157-178.

Fontagne, L., \& Freudenberg, M. (1997). Intral-industry trade: Methodological issues reconsidered. CEPII Working Paper, 97(1), 56-87.

Gray, H. P. (1979). Intra-industry trade: The effects of different levels of data aggregation. In H. Giersch (Ed.), On the Economies of Intra-Industry Trade. Tübingen: J.C.B. Mohr.

Greenway, D., \& Milner, C. (1986). The economics of intra-industry trade. Oxford: Basil Blackwell.

Grubel, H., \& Lloyd, P. (1975). Intra-industry trade: The theory and measurement of international trade in different products. London: Macmillan.

Markusen, J. R., \& Venables, A. J. (2002). The theory of endowment, intra-industry and multinational trade. Journal of International Economics, 52(10), 209-234.

Rasekhi, S. (2007). Methodology of intra-industry trade measuring: A case study for Iranian manufacturing. Iranian Journal of Economic Research, 81, 61-84.

Rasekhi, S. (2008). The study of intra-industry trade in agricultural products of Iran. American-Eurasian Journal of Agricultural \& Environmental Sciences, 2(1), 12-19.

Rasekhi, S., \& Shojaee, S. (2012). Country specific determinants of intra-industry trade types of agricultural sectors in selected developing countries. Iranian Economic Review, 16(31), 85- 99.

Shahbaz, M., \& Leitao, N. C. (2010). Intra-industry trade: The Pakistan experience international. Journal of Applied Economic, 7(1), 18-27.

Sawyer, W. C., Sprinkle, R. L., \& Tochkov, K. (2009). Pattern and determinants of intra-industry Trade in Asia. Journal of Asian Economics, 21, 485-493.

Vona, S. (1991). On the measurement of intra-industry trade: Some further thoughts. Weltwirtschaftliches Archiv, 127(4), $678-700$.

Xing, Y. (2007). Foreign direct investment and China's bilateral intra-industry trade with Japan and U.S. Journal of Asian Economics, 18, 687-700.

Yuqing, X. (2007). Foreign direct investment and China's bilateral intra-industry trade with Japan and the us. Journal of Asian Economics, 18(4), 685-700. 